\title{
Analisa dan Perancangan Sistem Informasi Penjualan Online (E-Commerce) Pada Swalayan Menggunakan Analisis Deskriptif
}

\author{
Restu Elides Zendrato, Anggie Yola Putri Simbolon, Tio Aenjely BR. Simatupang, Suhardi Trisno Silaban, M. Diarmansyah \\ Batubara \\ Program Studi Sistem Informasi Fakultas Teknologi dan Ilmu Komputer Universitas Prima Indonesia \\ Medan, Sumatera Utara, Indonesia \\ E-mail : restuzendrato1998@gmail.com
}

\begin{abstract}
ABSTRAK- Di era perkembangan yang semakin maju sekarang ini semua kebutuhan sudah bisa di dapatkan dengan cara yang cepat dan mudah dengan teknologi yang dari tahun ke tahun semakin canggih, misalnya dulu jika kita ingin membeli suatu barang/produk, pakaian dan sebagainya kita harus membeli langsung kepada penjual atau toko-toko yang tersedia. Dengan teknologi yang semakin canggih dan ilmu pengetahuhan yang semakin maju sekarang ini kita tidak perlu susah karena sekarang sudah terdapat toko-toko yang menjual barang yang kita butuhkan melalui internet yaitu dengan cara E-commerce atau yang biasa di kenal dengan toko online. Swalayan Helvetia merupakan supermarket yang menjual kebutuhan sehari-hari dan masih menggunakan sistem manual, Oleh sebab itu penulis ingin merancang dan membangun sebuah sistem informasi penjualan secara online yang bisa menjual barang kebutuhan sehari-hari dengan cepat dan mudah. Rancangan aplikasi ini akan dibuat dengan menggunakan analisis deskriptif, di mana sistem ini dibuat dengan cara bertahap mulai dari analisa, desain sistem, pembuatan sistem, implementasi, sampai maintenance, aplikasi ini dibuat agar masyarakat dapat terbantu dengan adanya aplikasi ini masyarakat tidak perlu lagi meluangkan waktu atau susah-susah datang ke tempat langsung untuk membeli sesuatu barang/produk. Tujuan perancangan website $e$-commerce ini adalah untuk memahami sistem penjualan dan strategi secara online untuk meningkatkan keuntungan dan kemudahan dalam bertransaksi.
\end{abstract}

Kata kunci : Analisis, E-Commerce, Web

\section{PENDAHULUAN}

Saat ini Teknologi sudah semakin canggih dan berkembang maju, dimana perangkat keras dan perangakat lunak yang dapat memudahkan suatu pekerjaan menjadi lebih efektif. Dengan adanya komputer untuk mempermudah pekerjaan manusia, dan perkembangan teknologi informasi yang begitu cepat sangat di perlukan di berbagai sektor untuk mendukung dan meningkatkan kualitas perusahaan. Perkembangan Perusahaan yang pada saat ini sangat membutuhkan yang dinamakan dengan komputer untuk memenuhi fasilitas teknologi informasi dan juga untuk meningkatkan strategi bisnis perusahaan. Dalam sebuah perusahaan sudah semestinya mempunyai suatu cara atau strategi bisnis yang tepat agar dapat tetap bersaing dalam dunia bisnis dan kepercayaan penuh dari konsumen sebagai jaminan untuk perusahaan tetap jalan.

Sistem informasi adalah kombinasi antara prosedur kerja, informasi, manusia dan teknologi informasi yang diorganisasikan untuk mencapai tujuan dalam sebuah organisasi. Dan internet adalah seluruh jaringan yang selalu terhubung satu sama yang lain, internet memberikan akses untuk layanan telekomunikasi dan sumber informasi untuk jutaan pemakainya.Dengan adanya jaringan internet segala transaksi dapat di lakukan secara global tanpa dibatasi waktu dan jarak, kemudahan inilah yang menjadi salah satu faktor utama yang mendukung kemajuan teknologi dengan berkembangnya electronic commerce (E-commerce), dengan adanya sistem e-commerce ini akan membantu tercapainya tujuan perusahaan yaitu mendapatkan keuntungan yang besar dan memperluas daerah penjualan atau pemasaran.

E-Commerce atau toko online merupakan salah satu konsep yang cukup berkembang dalam dunia internet, penggunaan sistem ini dapat menguntungkan banyak pihak, baik pihak konsumen, produsen maupun penjual. Dengan membangun dan merancang sebuah sistem penjualan online berbasis web (e-commerce), dimana perusahaan akan mendapat keuntungan yang banyak serta peningkatan kepuasan konsumen, dengan pemesanan dan strategi pemasaran yang menarik banyak konsumen baru serta mengurangi kesalahan dan resiko pada saat pemesanan.

Swalayan Helvetia adalah supermarket yang menjual kebutuhan sehari-hari, supermarket ini masih merupakan supermarket yang berkembang, sehingga untuk lebih meningkatkan citra perusahaan, sistem yang digunakan saat ini harus diperbaharui untuk mencapai perubahan yang dapat meningkatkan penjualan dan mempermudah transaksi. Sistem penjualan swalayan saat ini masih belum efektif, karena konsumen biasanya langsung ke swalayan untuk membeli barang/produk, dan konsumen tidak mengetahui persediaan produk, pesanan membutuhkan waktu yang lama untuk diproses. Oleh karena itu penulis membuat sistem informasi penjualan online berbasis web untuk meningkatkan penjualan yang efektif dan efisien dan 
membantu konsumen dalam bertransaksi, dan informasi mengenai supermarket, penjualan produk, harga produk, jumlah persediaan produk, dan pemesanan secara online ini dapat mempermudah konsumen dalam memesan produk/barang.

Berdasarkan permasalahan diatas maka perlu dibuat suatu sistem informasi penjualan online yang dapat menyelesaikan permasalahan yang ada pada swalayan helvetia saat ini, maka penulis melakukan penelitian yaitu "Analisa dan Perancangan Sistem Informasi Penjualan Online (E-Commerce) Pada Swalayan Menggunakan Analisis Deskriptif". Dengan menggunakan sistem penjualan online berbasis web ini diharapkan dapat membantu dan memberikan keuntungan bagi swalayan dan memberikan kemudahan bagi konsumen.

\section{METODE PENELITIAN}

\subsection{Metode Penelitian}

Metode deskriptif merupakan prosedur pemecahan masalah yang diselidiki dengan menggambarkan keadaan subjek atau objek dalam penelitian dapat berupa orang, lembaga, masyarakat dan yang lainnya yang pada saat sekarang berdasarkan fakta-fakta yang tampak atau apa adanya.

Tujuan dari penelitian deskriptif ini adalah menghasilkan gambaran akurat tentang sebuah kelompok, menggambarkan mekanisme sebuah proses atau hubungan, memberikan gambaran lengkap baik dalam bentuk verbal atau numerikal, menyajikan informasi dasar akan suatu hubungan, menciptakan seperangkat kategori dan mengklasifikasikan subjek penelitian. Metode ini juga menjelaskan seperangkat tahapan atau proses, serta untuk menyimpan informasi bersifat kontradiktif mengenai subjek penelitian.

Kelebihan penelitian secara deskriptif bermacammacam sebagai berikut:

- Sesuai dengan topik penelitian yang tidak memungkinkan untuk dijelaskan dalam bentuk angka, sehingga analisis yang hasil tetap maksimal dan mudah dipahami.

- Metode ini mampu memudahkan peneliti melakukan pengamatan pada situasi atau kondisi apa adanya dan tidak dibuat sesuka hati oleh peneliti.

- Dengan kombinasi antara penelitian kuantitatif dengan penelitian kualitatif

Kekurangan penelitian secara deskriptif bermacammacam sebagai berikut:

- Sifatnya tidak signifikan.

- Penelitian lebih cenderung subjektif.

- Verifikasi ulang Sulit untuk dilakukan, karena pengamatan dilakukan secara langsung dan di momen atau waktu tertentu situasinya tidak bisa diulang.

\subsection{Metode Pengumpulan Data}

Adapun jenis dan metode pengumpulan data dalam penelitian ini adalah sebagai berikut:

\section{Sumber Data Primer}

Data primer merupakan data yang diperoleh peneliti dengan cara meneliti langsung pada Swalayan.

\section{a. Observasi}

I Dalam tahap ini penulis melakukan wawancara langsung para karyawan, kasir, bagian keuangan dan pemilik untuk menanyakan tentang prosedur pembelian produk, penjualan, pencatatan persediaan barang, hingga laporan keuangan.

\section{b. Wawancara}

Wawancara merupakan teknik pengumpulan data dengan melakukan pengamatan langsung pada kasir dan Bagian persediaan stok produk.

\section{c. Studi literatur}

Cara untuk menyelesaikan persoalan dengan menelusuri sumber-sumber tulisan yang pernah dibuat sebelumnya dengan membaca buku, jurnal, artikel-artikel dan informasi yang berkaitan dengan objek penelitian.

\section{Sumber Data Sekunder}

Sumber data sekunder didapat dari dokumendokumen yang bersangkutan dengan objek yang diteliti yang ada di tempat dilakukannya penelitian. Dalam penelitian ini dilakukan pendekatan dengan metode deskriftif analisis, yaitu metode yang berusaha mengumpulkan, menyajikan, serta menganalisis data sehingga dapat memberikan gambaran yang cukup jelas atas objek yang diteliti. Dokumentasi yang didapat penulis adalah struk pembelian, laporan pendapatan, data barang, daftar bahan baku yang habis, daftar bahan baku yang dibeli, faktur, dan yang terakhir laporan pembelian produk.

\subsection{Prosedur Kerja}

Untuk membantu dalam penyusunan skripsi ini, maka perlu adanya: 


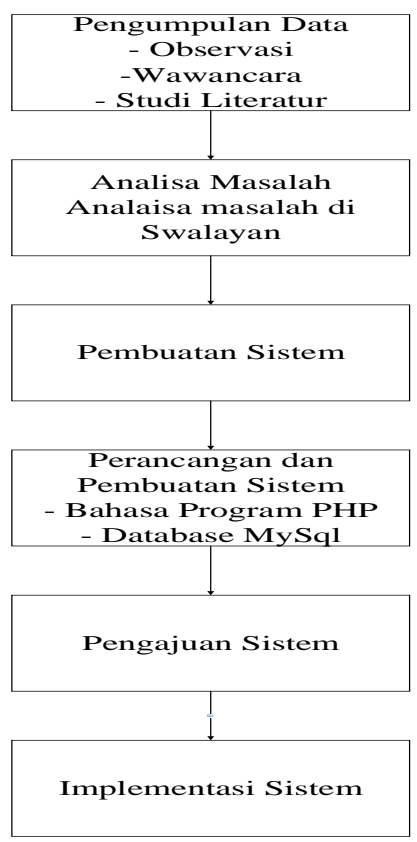

Gambar 2.1 Kerangka Kerja Penelitian

\section{HASIL DAN PEMBAHASAN}

\subsection{Analisa Kebutuhan}

Untuk membangun sistem informasi penjualan online berbasis web dibutuhkan analisa kebutuhan sebagai acuan dalam pembuatannya. Analisis kebutuhan untuk pembuatan aplikasi penjualan dapat dilakukan dengan tahapan dan proses seperti pada flowchart berikut ini:

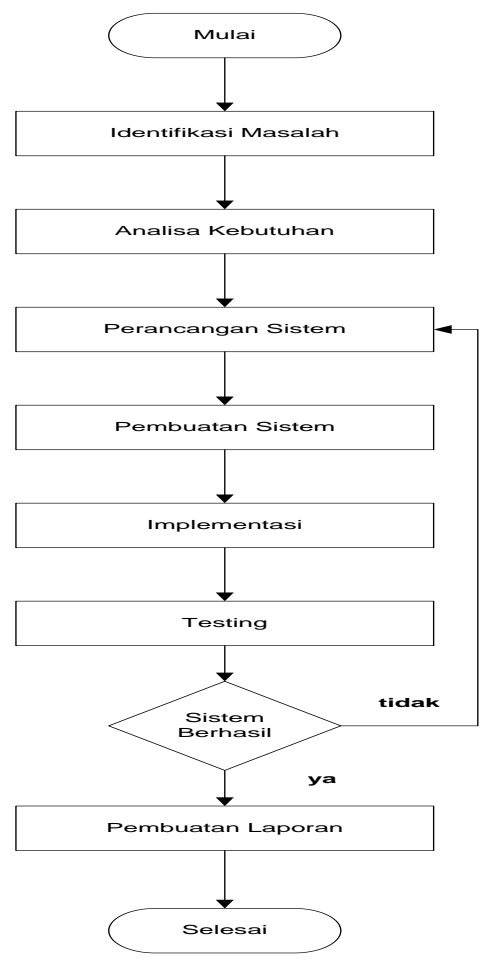

Gambar 3.1 flowchart
Dapat dilihat pada gambar 3.1 diatas, untuk melakukan analisis kebutuhan yang pertama dilakukan yaitu mengidentifikasi masalah, dan kekurangan yang ada. Kemudian mengidentifikasi masalah dilanjutkan dengan analisis kebutuhan yang diperlukan dalam pembuatan sistem informasi penjualan, dengan menganalisis sistem sebelumnya, dan sistem yang akan dibuat, kemudian yang dilakukan adalah merancang sistem, setelah perancangan sistem langkah selanjutnya yaitu pembuatan sistem informasi, dan Setelah sistem dibuat maka di implementasikan dan dilakukan testing/pengujian.

\subsection{Analisis Sistem}

\subsubsection{Use case Diagram}

Dalam Usecase Diagram ini terdapat satu aktor yang menjalankan aplikasi ini yaitu Admin. Dari gambar usecase dibawah admin dapat mengakses Data user yang mencakup akses pesanan user, data item barang penjualan, dan data pembelian yang dilakukan user. Admin juga memiliki akses terhadap Data item, data item disini adalah data stok barang yang dimiliki oleh swalayan, admin memiliki kemampuan untuk menambahkan barang, melakukan edit terhadap keterangan barang, dan menghapus barang yang di inginkan.

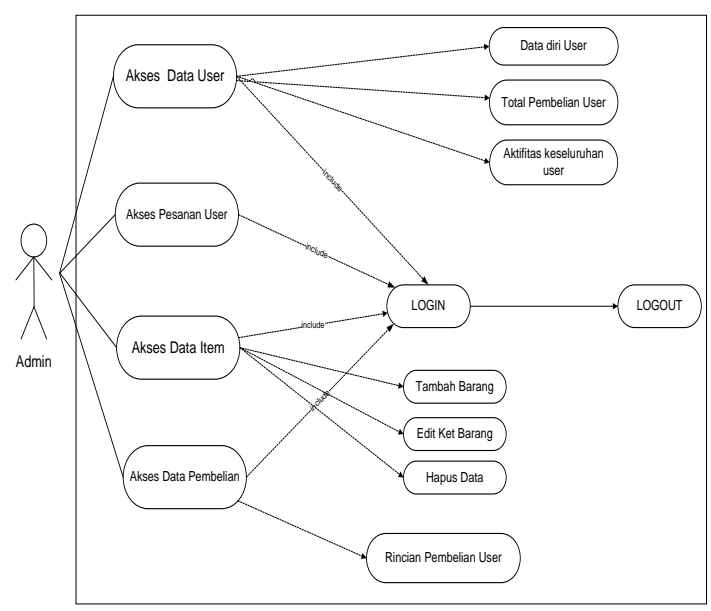

Gambar 3.2 Usecase Diagram Admin

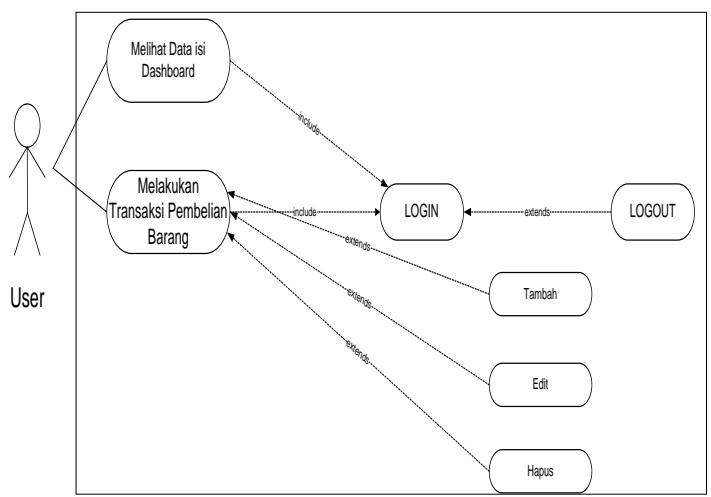

Gambar 3.3 Usecase Diagram User 
Dalam Gambar 3.3 Usecase Diagram ini terdapat satu aktor yang menggunakan aplikasi ini yaitu User. Dari gambar usecase diatas, user memiliki akses untuk melihat isi dari dashboard, dan melakukan transaksi pembelian. Transaksi pembelian yang dapat dilakukan oleh user adalah tambah barang yang ingin dibeli, melakukan edit barang yang ingin dibeli, dan melakukan hapus barang yang tidak ingin dibeli.

\subsection{Activity Diagram}

\subsubsection{Activity Diagram}

Activity Diagram adalah diagram yang dapat memodelkan proses-proses yang terjadi pada sebuah sistem. Activity diagram merupakan pengembangan dari Usecase yang memiliki alur aktivitas. Activity diagram yang akan diterapkan pada aplikasi ini adalah, sebagai berikut:

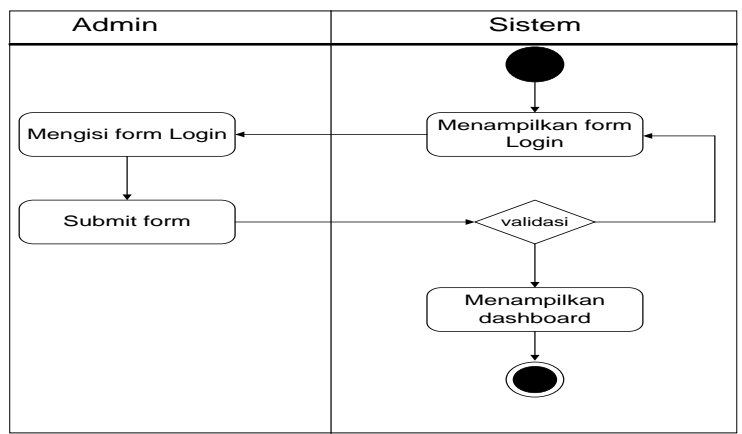

Gambar 3.4 Activity Diagram Login Admin

Gambar 3.4 ini merupakan activity diagram proses login admin. kemudian melakukan login, sistem akan menampilkan halaman login. Setelah itu admin mengisi form login dengan data yang ada. Setelah form diisi maka data yang dimasukkan di submit. Jika data yang di input valid maka admin akan dibawa ke halaman dashboard. Jika data yang di input tidak valid maka admin akan dibawa kembali ke halaman login.

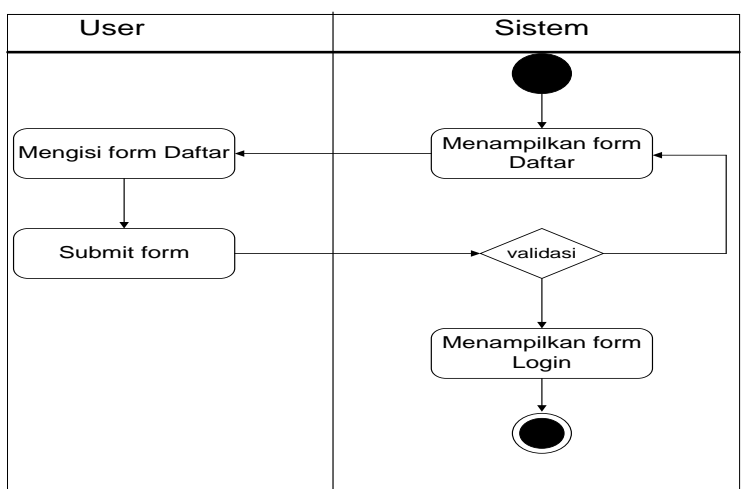

Gambar 3.5 Activity Diagram Daftar User

Gambar 3.5 ini merupakan activity diagram proses daftar, proses ini hanya dimiliki oleh user. Untuk melakukan daftar, sistem akan menampilkan halaman daftar. Setelah itu user mengisi form di halaman daftar dengan data pribadinya. Setelah form diisi maka data yang dimasukkan di submit. Jika data valid maka user akan dibawa ke halaman login. Jika data tidak valid maka user akan dibawa kembali ke halaman daftar.

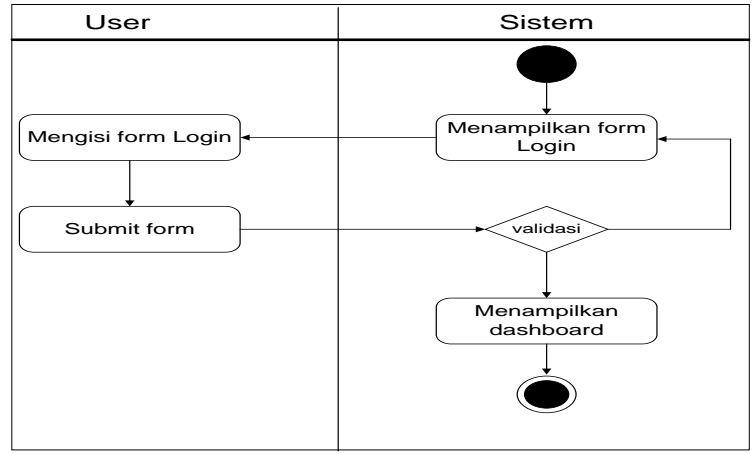

Gambar 3.6 Activity Diagram Login (User)

Gambar 3.6 ini merupakan activity diagram proses login user. Untuk melakukan login, sistem akan menampilkan halaman login. Setelah itu user mengisi form login dengan data yang ada. Setelah form di isi maka data yang di input di submit. Jika data yang di input valid maka user akan dibawa ke halaman dashboard. Jika data yang di input tidak valid maka user akan dibawa kembali ke halaman login.

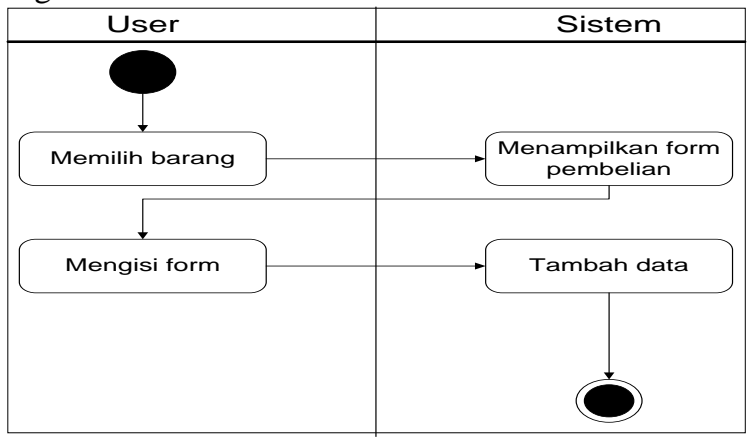

\section{Gambar 3.7 Activity Diagram Pembelian (User)}

Gambar 3.7 diatas merupakan activity diagram pembelian user. Untuk melakukan pembelian, user pertama harus memilih barang yang ingin dibeli pada dashboard, lalu user mengisi form yang harus diisi untuk proses pembelian. Setelah form diisi maka data akan ditambahkan ke database, dan ditampilkan juga nantinya ke dashboard admin.

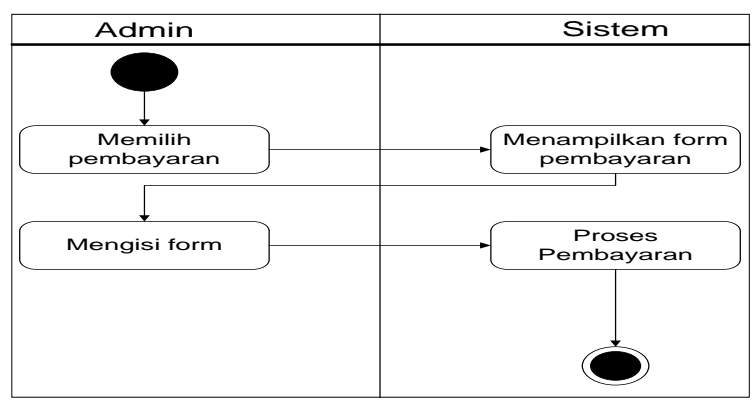

Gambar 3.8 Activity Diagram Pembayaran user 
Gambar 3.8 diatas merupakan activity diagram pembayaran user. Untuk melakukan pembayaran, user pertama harus memilih pembayaran atau checkout, lalu user diminta untuk mengisi form yang harus diisi untuk proses pembayaran. Setelah form di isi maka data pembayaran akan ditambahkan ke database, dan ditampilkan juga nantinya ke dashboard admin. Selanjutnya barang yang sudah dibayar tadi akan dikirim ke lokasi tempat tinggal user sesuai alamat yang diisi pada form pembayaran sebelumnya.

\subsection{Implementasi Sistem}

Tampilan halaman login admin ini digunakan untuk masuk kedalam menu utama yaitu dengan memasukkan username dan password dengan tepat, hingga nanti akan muncul login sukses, seperti pada gambar 3.9.

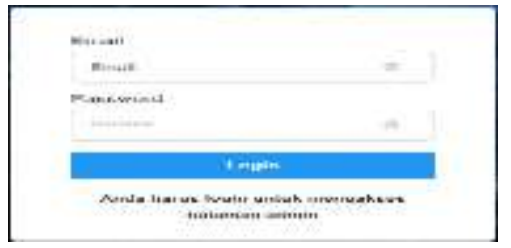

Gambar 3.9 Halaman Login Admin

Dan selanjutnya setelah login berhasil maka akan menampilkan dashboard admin yang dimana nantinya admin sebagai operator untuk memantau penjulan pada swalayan mandiri helvetia dan admin juga dapat menambah, mengubah dan menghapus stok produk/barang. Berikut tampilan daftar barang dapat dilihat pada gambar 3.10

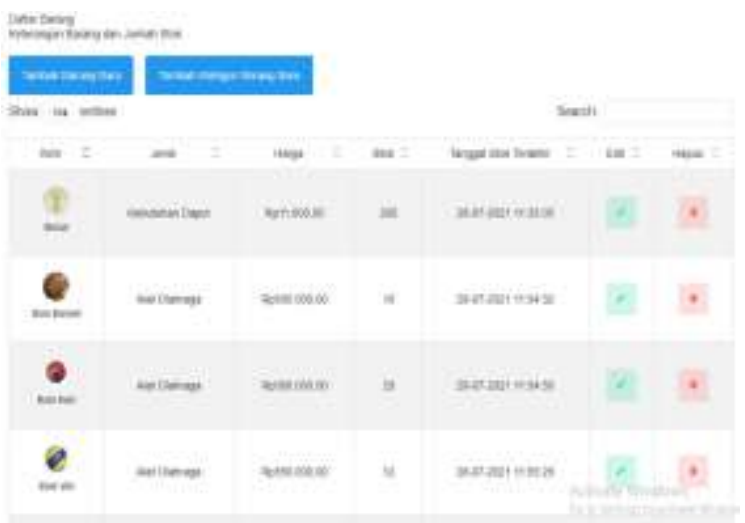

Gambar 3.10 Daftar Barang

Kemudian tampilan dibawah ini untuk menambah barang/produk yang akan masuk, maka admin dapat menginput data seperti nama produk, kategori, harga dan jumlah stok dan selanjutnya dapat untuk menambah gambar produk,seperti pada gambar 3.11

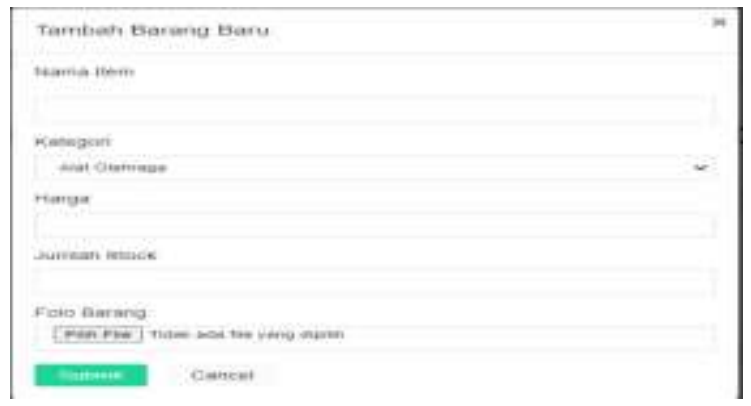

Gambar 3.11 Tampilan Tambah Barang

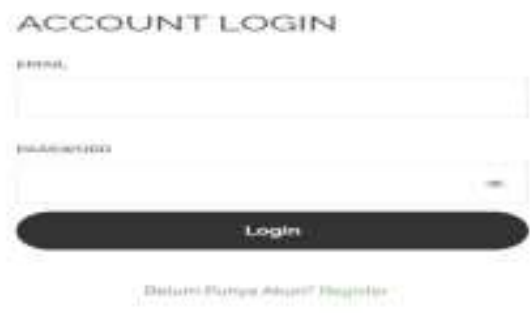

Gambar 3.12 Tampilan Login User

Pada gambar 3.12 diatas Tampilan halaman login user ini digunakan untuk masuk kedalam menu utama yaitu dengan memasukkan email dan password dengan tepat, dan untuk yang baru pertama kali membuat akun bisa melakukan register terlebih dahulu untuk membuat akun baru, hingga nanti akan muncul login sukses.

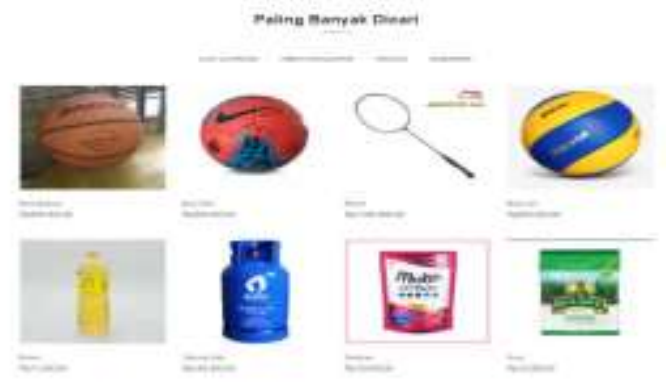

Gambar 3.13 Tampilan Barang/Produk

Dan kemudian setelah login user berhasil, setelah itu akan masuk di menu utama dimana user dapat berbelanja atau memilih barang/produk yang akan dibeli sesuai kebutuhan konsumen seperti pada gambar 3.13 Tampilan Barang/Produk.

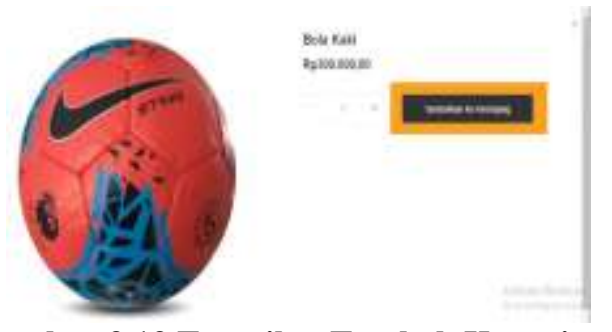

Gambar 3.13 Tampilan Tambah Keranjang 


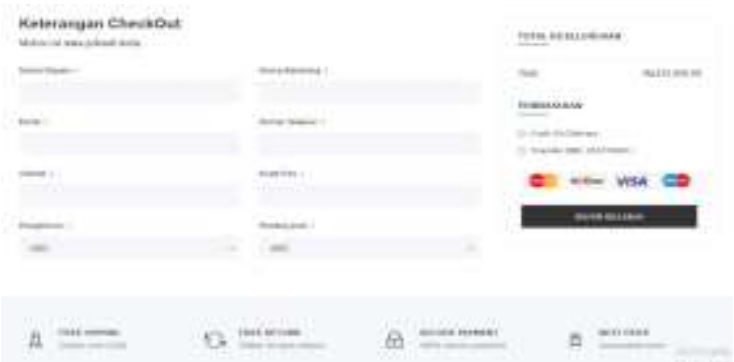

Gambar 3.14 Tampilan CheckOut

Tampilan gambar 3.13 di atas adalah konsumen yang telah memilih barang/produk yang akan dibeli, konsumen dapat menambah pada keranjang sesuai kebutuhan konsumen dan setelah konsumen selesai untuk membeli barang/produk yang di inginkan, konsumen dapat melakukan transaksi terlebih dahulu agar barang/produk yang beli dapat segera di proses oleh admin.

Tampilan gambar 3.14 di atas adalah Tampilan CheckOut dimana konsumen dapat nelakukan transaksi untuk segera di proses barang/produk yang telah dibeli dan kemudian konsumen di wajibkan untuk mengisi data seperti, nama, email, alamat, nomor telepon, kode pos,pengiriman dan memilih metode pembayaran.

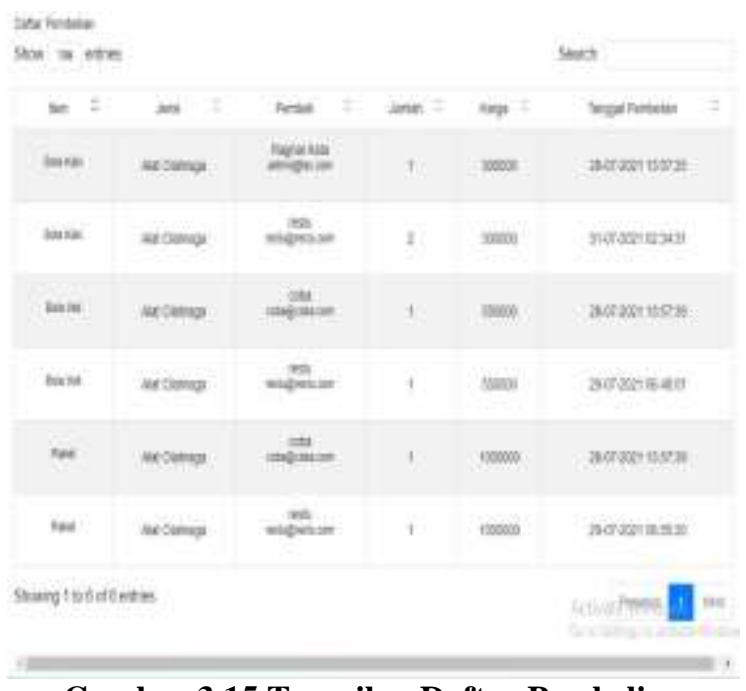

Gambar 3.15 Tampilan Daftar Pembelian

Tampilan gambar 3.15 di atas adalah tampilan daftar pembelian atau transaksi yang telah di lakukan oleh konsumen dan akan di proses oleh admin untuk packing kemudian barang/produk akan dikirim melalui kurir ke tempat tujuan.

Tampilan pada gambar 3.16 di bawah ini adalah tampilan laporan penjualan data transaksi yang telah di lakukan oleh konsumen membeli barang/produk

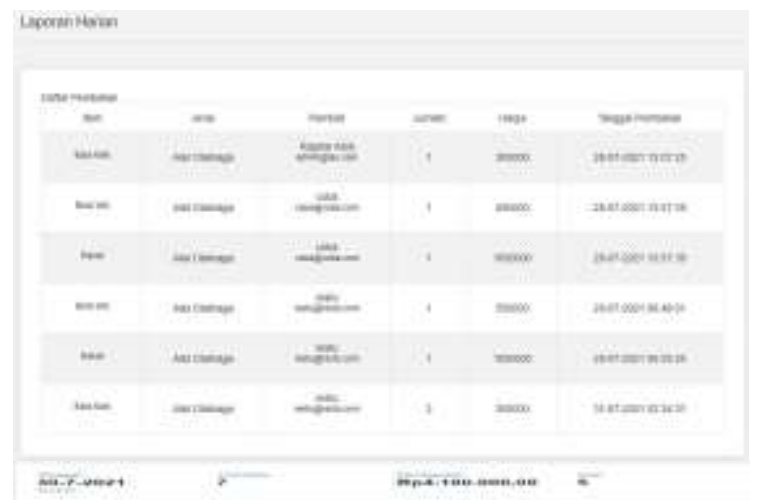

Gambar 3.16 Tampilan Laporan

\section{PENUTUP}

\subsection{Kesimpulan}

Website penjualan online (e-commerce) yang dirancang dan dibangun pada swalayan mandiri helvetia bukan untuk menggantikan sistem yang lama tetapi merupakan penambahan sistem yaitu dengan melakukan transaksi secara online, agar memudahkan konsumen untuk pemesanan produk/barang yang dimana bisnis perusahaan yang sebelumnya masih bersifat offline. Berdasarkan hasil dari analisis dan perancangan sistem yang dibuat, maka dapat ditarik kesimpulan sebagai berikut:

1. Website penjualan ini dapat membantu swalayan untuk memperluas pemasaran dan penjualan kepada konsumen menjadi lebih cepat dan mudah mendapatkan informasi tentang barang/produk tanpa harus datang ke swalayan.

2. Sistem penjualan online (e-commerce) pada swalayan dapat memudahkan proses transaksi yang selama ini sifatnya konvensional menjadi lebih modern dengan transaksi online.

3. Diharapkan website penjualan ini dapat mempermudah dalam pembuatan laporan penjualan yang sebelumnya masih manual.

\subsection{Saran}

Sistem perancangan website penjualan online (e-commerce) pada swalayan, berikut ini beberapa saran yang mungkin dapat menjadi bahan pertimbangan untuk meningkatkan pemasaran dan penjualan serta untuk meningkatkan kualitas swlayan helvetia dimasa yang akan datang diantaranya yaitu:

1. Sebaiknya sistem informasi penjualan online (ecommerce) ini dapat di implementasikan untuk memudahkan dalam bertransaksi

2. Pengguanaan sistem ini sebaiknya dilakukan oleh admin yang telah menguasai bagian ini guna menjaga keamanan data

Dilakukan maintenance yang berkelanjutan terhadap sistem baru ini supaya mendapatkan hasil yang diterapkan 
JUSIKOM PRIMA (Jurnal Sistem Informasi dan Ilmu Komputer Prima)

Vol. 5 No. 1, Agustus 2021

E-ISSN : 2580-2879

\section{DAFTAR PUSTAKA}

[1] Afatta, Hanif 2017. Analisis dan Perancangan Sistem Informasi: Untuk Keunggulan Bersaing Perusahaan dan Organisasi Modren. Yogyakarta Adi Offset.

[2] Bayu Tri Sakti, Fandi Indra Pratama Tahun 2020. Perancangan Aplikasi Penjualan

Berbasis Web Pada CV.Jawi, Semarang

[3] D.Susandi, S.Sukisno. 2017. Sistem Penjualan Berbasis E-commerce Mengunkan Metode Objek Oriented Pada Distro Dlapak/Street Wear. Jurnal Sistem Informasi, Vol 4

[4] Enterprise, Jubillee. 2017. Otodidak MySQL untuk pemula. Jakarta: Elex media komputindo.

[5] Ismiatun 2018. Perancangan dan Implemntasi Aplikasi Web Sistem Penjualan Suku Cabang Gondola pada CV Yoga Perkasa Mandiri. Universitas Respati Indonesia, Jakarta.

[6] R.Irviani, Kasmi. 2018. Perancangan Aplikasi E-commerce Berbasis Android pada Kelompok Swadaya Masyarakat Desa Marga Karya Pringsewu. Jurnal ilmu komputer. Vol 4 No. 1

[7] Supardi, yuniar. 2018. Semua Bisa Menjadi Programmer Codelgniter Basic. Jakarta: Elex media komputindo.

[8] S,Sarosa. 2017. Metode Pengembangan Sistem. Jakarta: Indeks Jakarta.

[9] Suherman, F.Aziz. 2018. Rancang Bangun Aplikasi Layanan E-commerce -Tempat Oleh-oleh Wisata Anyer. Jurnal Protekinfo, Vol 5 No.September

[10] Yudin mulyanto. 2020. Rancang Bangun Sistem Informasi Penjualan Pada Toko Omg Berbasis Web, Jurnal Informatika Teknologi dan Sains: Vol. 2 No.1 